\title{
Flemming Christiansen, Chinatown, Europe: An Exploration of Overseas Chinese Identity in the 1990s
}

London, New York, RoutledgeCurzon, 2003, 240 p.

Live Yu-Sion

\section{OpenEdition}

Journals

Édition électronique

URL : http://journals.openedition.org/chinaperspectives/841

DOI : 10.4000/chinaperspectives.841

ISSN : 1996-4617

Éditeur

Centre d'étude français sur la Chine contemporaine

Édition imprimée

Date de publication : 1 juillet 2004

ISSN : 2070-3449

\section{Référence électronique}

Live Yu-Sion, «Flemming Christiansen, Chinatown, Europe: An Exploration of Overseas Chinese Identity in the 1990s », China Perspectives [En ligne], 54 | July- August 2004, mis en ligne le 25 avril 2007, consulté le 23 septembre 2020. URL : http://journals.openedition.org/chinaperspectives/841 . DOI : https://doi.org/10.4000/chinaperspectives.841

Ce document a été généré automatiquement le 23 septembre 2020.

(c) All rights reserved 


\title{
Flemming Christiansen, Chinatown, Europe: An Exploration of Overseas Chinese Identity in the 1990s
}

\author{
London, New York, RoutledgeCurzon, 2003, 240 p.
}

\author{
Live Yu-Sion
}

\section{NOTE DE L'ÉDITEUR}

Translated from the French original by Philip Liddell

1 There have been few studies on Chinese communities in Europe, as is apparent from the bibliography in Flemming Christiansen's book. This one fills a significant gap. There are seven chapters, all devoted to various questions of identity. At the start of the book, its author recalls anthropological arguments (primitivist, instrumentalist, cultural...) on the question of ethnicity, and runs through the various policies (integration, assimilation...) adopted in European countries in response to the presence of foreigners on their soil, describing the influence of these policies on the structuration of the Chinatowns that have grown up there.

Christiansen goes on to highlight the concepts so far developed on Chinese identity. The Chinese themselves define the first criterion of identification as genetic inheritance. This blood descent (xuetong), which has been the basis of nationalism or patriotism, has for a long time dominated China's policy towards the overseas Chinese: a Chinese person is one who is born of Chinese parents and who has a right to Chinese nationality in accordance with jus sanguinis. However, the Chinese in Europe are not of one mind over this biological link; its interpretation varies from one person to the next and from one situation to another. To define themselves, the Chinese also refer back to their ancestral village or to their home region in China. These roots confer on them a local identity anchored in a specific territory. 
3 Yet, the language spoken by an individual person remains the most pertinent criterion for defining his or her membership of a group. Two linguistic groups are examined and cited as examples of social cohesion and proof of identity: the Siyi, originating in Guangdong (better known by the Cantonese pronunciation of Si-Yap) and the Qingtian from Zhejiang. The various waves and forms of Chinese migration to European countries (as contract workers, students, economic migrants or illegal immigrants), from the nineteenth century to the present day, help us to grasp the heterogeneity of the geographic and cultural origins of the Chinese community in Europe.

4 And in Europe, it is the Chinatowns that most symbolise the Chinese presence. But what do they represent for Europeans, these urban spaces bedecked with Chinese cultural symbols? What role and what function do they perform for the Chinese people who live in them? For Westerners, the word Chinatown conjures up a whole range of ideas, from the fantastic to the real (ghettos, the yellow peril, drugs, the Chinese mafia, a concentration of illegal activities ... but also the porticos or arches over streets leading into Chinese districts, tiger and dragon dances, kung-fu, fireworks, colourful processions during the big traditional festivals and so on).

5 By recounting how Chinese districts developed over the past two decades, Christiansen challenges the status of such a vision. There are no Chinatowns in German cities or in the Scandinavian countries. The Chinatowns in Europe, unlike those in the United States or South-East Asia, are not ethnic enclaves holding populations that are shut in on themselves, illiterate and low-skilled. They are open, and mainly used by the leaders of community institutions whose undeclared aim is to offer to the Europeans an image that corresponds to their expectations and to give a structure to the activities of Chinese people, business, social, cultural, political and economic (turning Chinese cultural symbols to commercial use, arranging for the Chinese to vote in local urban elections, setting up clubs for senior citizens, organising traditional festivals, and so on).

6 One of the means by which new immigrants can integrate economically is trade. Economic organisation rests upon networks of individuals and institutional structures, among which the best known example is the tontine system. Many Chinese people have recourse to it to build up some capital and establish a business enterprise. But is tontine peculiar to the Chinese? Caribbean people of African origin, deported to the British West Indies in the time of the slave trade, and North African women migrants to France have also used this system of staggered credit to get their businesses off the ground.

7 In our view, when the Chinatowns array themselves in community institutions (associations, places of worship, leisure centres ...), in multicoloured neon signs in Chinese characters, in architectural exoticism (arches or porticos) and so on, we may attribute the exchanges between the Chinese and the local political authorities (the city council or the town planners ...) not only to cultural or psychological factors but also to the current situation, during negotiations, talks, times of decision ... in order to develop or to revitalise the Chinese areas. Exchanges of influence between the two sides are created through a process of interpretation. Everyday social practices are the result of the continuing activity of individual people.

8 From this point of view, Chinatowns also play other, more symbolic, roles. Chinese areas are, for many members of the diaspora, the embodiment of their national memory; and they are intimately linked to their everyday lives. Such places come to be, 
in the course of time, part of their identity. Thus, the Chinese areas often fulfil the function of staging-post for the newly arrived migrants, a first step towards eventual integration into a new social world. These urban spaces are part of their identity. Individual identity interacts with the social environment where all parties have their being.

9 Flemming Christiansen's book takes its place in the mainstream of studies on interethnic and intercultural relations. The arguments developed by the interactionist movement within these studies relativise the cultural dimension of social agents; they emphasise the social connections or the social relationships that are meaningful. A social group may only acquire ethnic status when it is perceived and considered as such in terms of its culture and its social or professional position in any given society. 